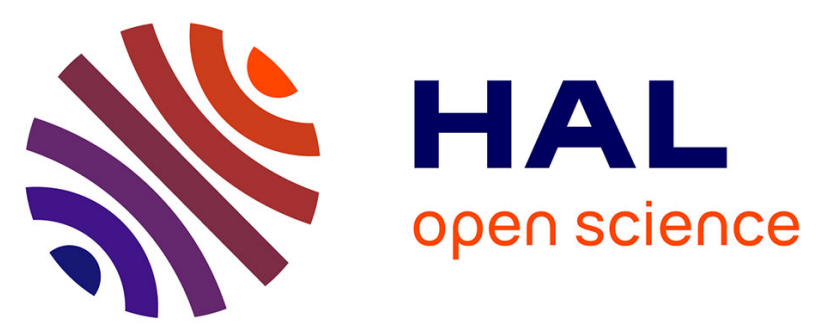

\title{
Chloramination of nitrogenous contaminants (pharmaceuticals and pesticides): NDMA and halogenated DBPs formation
}

\author{
Julien Le Roux, Hervé Gallard, Jean-Philippe Croué
}

\section{- To cite this version:}

Julien Le Roux, Hervé Gallard, Jean-Philippe Croué. Chloramination of nitrogenous contaminants (pharmaceuticals and pesticides): NDMA and halogenated DBPs formation. Water Research, 2011, 45 (10), http://www.sciencedirect.com/science/article/pii/S0043135411001461. 10.1016/j.watres.2011.03.035 . hal-01201554

\section{HAL Id: hal-01201554 \\ https://hal-enpc.archives-ouvertes.fr/hal-01201554}

Submitted on 17 Sep 2015

HAL is a multi-disciplinary open access archive for the deposit and dissemination of scientific research documents, whether they are published or not. The documents may come from teaching and research institutions in France or abroad, or from public or private research centers.
L'archive ouverte pluridisciplinaire $\mathbf{H A L}$, est destinée au dépôt et à la diffusion de documents scientifiques de niveau recherche, publiés ou non, émanant des établissements d'enseignement et de recherche français ou étrangers, des laboratoires publics ou privés.

$$
\text { Copyright }
$$




\title{
Chloramination of nitrogenous contaminants (pharmaceuticals and
} pesticides): NDMA and halogenated DBPs formation

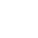

\author{
JULIEN LE ROUX, HERVÉ GALLARD* AND JEAN-PHILIPPE CROUÉ1
}

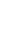

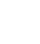

(

Laboratoire de Chimie et Microbiologie de l'Eau (CNRS UMR 6008), Université de Poitiers - ENSIP, 40 Avenue du

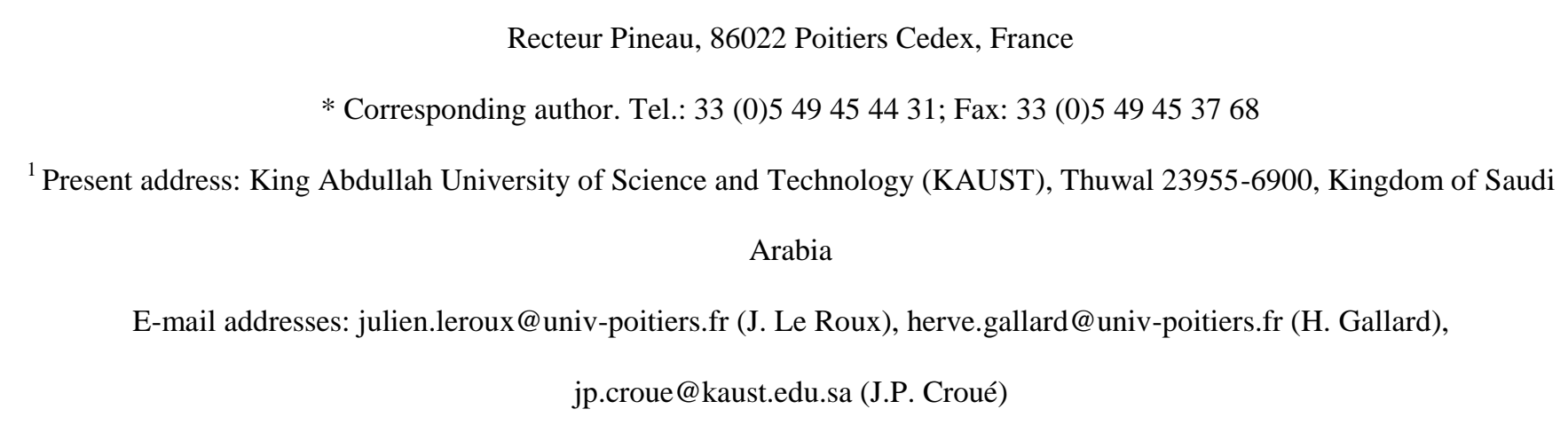

${ }^{1}$ Present address: King Abdullah University of Science and Technology (KAUST), Thuwal 23955-6900, Kingdom of Saudi Arabia E-mail addresses: julien.leroux@univ-poitiers.fr (J. Le Roux), herve.gallard@univ-poitiers.fr (H. Gallard), jp.croue@kaust.edu.sa (J.P. Croué) 3

\section{Abstract}

Disinfection with chloramines is often used to reduce the production of regulated disinfection by-products (DBPs) such as trihalomethanes (THMs) and haloacetic acids (HAAs). However, chloramination can lead to the formation of N-nitrosamines, including N-nitrosodimethylamine (NDMA), a probable human carcinogen. Previous research used dimethylamine (DMA) as a model precursor of NDMA, but certain widely used tertiary dimethylamines (e.g. the pharmaceutical ranitidine) show much higher conversion rates to NDMA than DMA. This study investigates the 1 NDMA formation potential of several tertiary amines including pharmaceuticals and herbicides. The 2 reactivity of these molecules with monochloramine $\left(\mathrm{NH}_{2} \mathrm{Cl}\right)$ is studied through the formation of NDMA, 3 and other halogenated DBPs such as haloacetonitriles (HANs) and AOX (Adsorbable Organic Halides). 4 Several compounds investigated formed NDMA in greater amounts than DMA, revealing the 
25 importance of structural characteristics of tertiary amines for NDMA formation. Among these

26 compounds, the pharmaceutical ranitidine showed the highest molar conversion to NDMA. The pH and

27 dissolved oxygen content of the solution were found to play a major role for the formation of NDMA

28 from ranitidine. NDMA was formed in higher amounts at $\mathrm{pH}$ around $\mathrm{pH} 8$ and a lower concentration of

29 dissolved oxygen dramatically decreased NDMA yields. These findings seem to indicate that

30 dichloramine $\left(\mathrm{NHCl}_{2}\right)$ is not the major oxidant involved in the formation of NDMA from ranitidine,

31 results in contradiction with the reaction mechanisms proposed in the literature. Dissolved oxygen was

32 also found to influence the formation of other oxygen-containing DBPs (i.e. trichloronitromethane and

33 haloketones). The results of this study identify several anthropogenic precursors of NDMA, indicating

34 that chloramination of waters impacted by these tertiary amines could lead to the formation of

35 significant amounts of NDMA and other non-regulated DBPs of potential health concern (e.g.

36 dichloroacetonitrile or trichloronitromethane). This could be of particular importance for the

37 chloramination of wastewater effluents, especially during water reuse processes.

Keywords

NDMA, Nitrosamine, Chloramination, Disinfection By-products, Ranitidine 
50 A large diversity of disinfection by-products (DBPs) are formed during water treatment processes using

51 chlorination, including trihalomethanes (THMs) and haloacetic acids (HAAs). Disinfection with

52 chloramines is known to significantly reduce the formation of regulated DBPs as compared to

53 chlorination. However, chloramination favors the formation of $N$-nitrosamines, including

$54 \mathrm{~N}$-nitrosodimethylamine (NDMA). The US Environmental Protection Agency classifies NDMA as a

55 probable human carcinogen, evaluating a $10^{-6}$ risk level of cancer from NDMA concentration at

$56 \quad 0.7 \mathrm{ng} / \mathrm{L}$ in drinking water (U.S. Environmental Protection Agency, 1987). Over the last decade, interest

57 has been growing about NDMA formation during water treatment process. Several studies examined the

58 mechanisms explaining the formation of NDMA during chlorination and chloramination. In most

59 studies, dimethylamine (DMA) served as the model NDMA precursor (Choi and Valentine, 2002a; Choi

60 and Valentine, 2002b; Choi and Valentine, 2003; Choi et al., 2002; Mitch and Sedlak, 2002; Schreiber

61 and Mitch, 2005; Schreiber and Mitch, 2006). However, some studies indicated that the amount of

62 dimethylamine present in surface waters (Gerecke and Sedlak, 2003) or secondary municipal

63 wastewaters (Mitch and Sedlak, 2004) are not sufficient to explain the amount of NDMA formed. The

64 role of tertiary amines presenting dimethylamine functional groups has been pointed out (Mitch and

65 Sedlak, 2004; Schmidt et al., 2006). Recent studies looked at diuron as a precursor of NDMA. Results

66 showed that the molar conversion rate is relatively low $(<1.5 \%$ of diuron forms NDMA) (Chen and

67 Young, 2008; Chen and Young, 2009). Another tertiary amine ranitidine, a histamine antagonist widely

68 used for peptic ulcer treatment was found to be an important NDMA precursor (62.9\% NDMA yield

69 obtained by Schmidt et al., 2006 and $89.9 \%$ by Shen and Andrews, 2011). Other tertiary amines led to

70 less or equal NDMA formation than DMA, revealing the importance of structural characteristics of

71 tertiary amine compounds for NDMA formation (Schmidt et al., 2006). Shen and Andrews (2011)

72 demonstrated that several tertiary amines including pharmaceuticals and personal care products are 
73 nitrosamine precursors during chloramines disinfection. According to these authors, the presence of

74 electron donating group such as furan can increase the electron density on the nitrogen atom and then

75 favors the reaction with chlorine leading to high NDMA yields observed with some pharmaceuticals

76 (especially ranitidine). Ranitidine is sold worldwide as a gastrointestinal drug and has been detected at

77 concentrations ranging from $70 \mathrm{ng} / \mathrm{L}$ to $540 \mathrm{ng} / \mathrm{L}$ in primary effluents of wastewater treatment plants

78 (WWTP) in Spain (Radjenovic et al., 2009) and at 10 ng/L in several surface waters (Kolpin et al.,

2002; Zuccato et al., 2000). Ranitidine and other pharmaceuticals are not well removed by biological

80 treatments and can be found in river waters receiving the WWTP effluents (Castiglioni et al., 2006;

81 Radjenovic et al., 2009). Chloramination of wastewaters (e.g. for wastewater reuse purposes) impacted

82 by pharmaceuticals is of great concern because of the potential risk of NDMA formation.

83 NDMA formation occurring during chloramination has previously been explained as a nucleophilic

84 substitution reaction between monochloramine $\left(\mathrm{NH}_{2} \mathrm{Cl}\right)$ and dimethylamine (DMA) to form an

unsymmetrical dimethylhydrazine intermediate (UDMH) (Choi and Valentine, 2002b; Choi et al., 2002;

Mitch and Sedlak, 2002). UDMH is then rapidly oxidized by $\mathrm{NH}_{2} \mathrm{Cl}$ to NDMA at $<3 \%$ yields. Over the

87 past few years, studies have addressed the importance of chloramines speciation and dissolved oxygen

88 (Schreiber and Mitch, 2006). Dichloramine $\left(\mathrm{NHCl}_{2}\right)$ was found to contribute to the production of

89 NDMA during chloramine disinfection, occurring through the formation of a chlorinated UDMH

90 (UDMH-Cl) as an intermediate rather than $\mathrm{UDMH}$. Enhancing the formation of $\mathrm{NHCl}_{2}$ by increasing

91 the $\mathrm{Cl}: \mathrm{N}$ ratio also lead to higher yields of NDMA during chloramination of tertiary amines (Shen and

92 Andrews, 2011). Dissolved oxygen was also described as a critical parameter (Schreiber and Mitch,

93 2006). The authors proposed that the last step of the formation of NDMA consists in the incorporation

94 of dissolved $\mathrm{O}_{2}$ into UDMH-Cl, which would then lead to NDMA.

95 Degradation of tertiary amines may form other nitrogenous disinfection byproducts (N-DBPs) of

96 potentially health concern, such as haloacetonitriles (HANs), halonitromethanes (HNMs), haloketones 
(HKs) or cyanogen chloride $(\mathrm{CNCl})$. HANs have been proved to be more toxic than HAAs and other regulated DBPs (Muellner et al., 2007; Muellner et al., 2007). Trichloronitromethane (TCNM), also known as chloropicrin, was the first of the HNMs to be identified as a DBP in drinking water (Hoigne and Bader, 1988; Thibaud et al., 1987). Potential health effects of HNMs have already been studied

101 (National Cancer Institute, 1978; Schneider et al., 1999). They were found to be more mutagenic than 102 the corresponding halomethanes, and TCNM has been demonstrated to be particularly genotoxic (Plewa et al., 2004). TCNM formation mechanisms have been proposed by chlorination and chloramination of monomethylamine and n-propylamine (Joo and Mitch, 2007). TCNM formation is expected to increase with $\mathrm{pH}$ during chlorination, and to be more important during chlorination than during chloramination. TCNM formation from chlorination of lake waters was 40 times lower than that of chloroform (Hoigne and Bader, 1988). Major haloketones (HKs) identified in chlorinated or chloraminated waters are 1,1-dichloro-2-propanone (1,1-DCP) and 1,1,1-trichloro-2-propanone (1,1,1-TCP). DCAN, 1,1-DCP and $\mathrm{CNCl}$ formation were found to decrease when increasing $\mathrm{pH}$, with maximum yields around $\mathrm{pH}$ 5-6 (Yang et al., 2007). DCAN formation during chloramination was much lower than during chlorination, whereas $\mathrm{CNCl}$ and 1,1-DCP yields were higher in chloraminated water (Yang et al., 2007). The goal of this study was to investigate the reactivity of several nitrogen-containing organic compounds with monochloramine, through the formation of NDMA, HANs and AOX (Adsorbable

114 Organic Halides). Model compounds investigated included three herbicides (diuron, isoproturon, 115 trifluralin) and five pharmaceuticals: ranitidine (peptic ulcer treatment); doxepin and amitriptyline 116 (tricyclic antidepressants); mifepristone (an abortifacient) and minocycline (an antibiotic used for acne 117 treatment). All of them are tertiary amines presenting DMA functional groups. These anthropogenic 118 compounds are likely to enter natural waters via wastewater discharges (i.e. pharmaceuticals) or 119 agricultural runoff (i.e. herbicides). Because our objective was to study byproducts formation 120 mechanisms, solutions of model compounds were prepared at concentrations that are significantly 
121 higher than what can be found in natural waters or wastewater effluents. As a result, DBPs were formed 122 at relatively high concentrations that are not likely to be found in treated waters. The influence of 123 several parameters (i.e. nitrites concentration, $\mathrm{pH}$, chloramines speciation and dissolved oxygen 124 concentration) was investigated in order to better understand the reaction mechanisms that lead to the 125 formation of NDMA and some other DBPs (HANs, HKs, TCNM, AOX) during chloramination of 126 tertiary amines.

\section{Materials and methods}

\subsection{Materials}

130 All experiments were conducted using deionized water (Milli-Q, Millipore) buffered with sodium 131 acetate $(\mathrm{pH}=4.0-5.5)$, a mixture of sodium phosphate monobasic and sodium phosphate dibasic $132(\mathrm{pH}=7.0-8.5)$, or sodium carbonate $(\mathrm{pH}=10) . \mathrm{pH}$ values were adjusted as needed using sodium 133 hydroxide or sulfuric acid (0.1 N, Fisher Scientific). Fluka Analytical methyl tert-butyl ether (>99\%), 134 Fisher Scientific methylene chloride (GLC grade) and Carlo Erba methanol (>99.9\%) were used without 135 further purification. Amitriptyline (>98\%), diuron (>98\%), doxepin (>98\%), isoproturon (99.8\%), 136 mifepristone (>98\%), minocycline (92\%, 8\% water), ranitidine and trifluralin (>99\%) were used without 137 further purification and were supplied through Sigma-Aldrich. Sodium hypochlorite (NaOCl, 13\%, 138 Acros Organics) and ammonium chloride (Fisher Scientific, 99.9\%) were used to prepare chloramine 139 reagents. Anhydrous sodium sulfite (Fisher Scientific) was used to quench residual chloramines.

140 Isotopically labeled standards, $\left[6-{ }^{2} \mathrm{H}\right] N$-nitrosodimethylamine (NDMA-d6, 98\%, $1 \mathrm{mg} \cdot \mathrm{mL}^{-1}$ in 141 methylene chloride) and $\left[14-{ }^{2} \mathrm{H}\right] N$-nitrosodi-n-propylamine (DPNA-d14, 98\%, $1 \mathrm{mg} \cdot \mathrm{mL}^{-1}$ in methylene 142 chloride) were obtained from Cambridge Isotope Laboratories (Andover, MA, USA). A standard 143 solution containing seven $N$-nitrosamines $(2000 \mu \mathrm{g} / \mathrm{mL}$ each in methylene chloride) was purchased from 144 Supelco (Sigma-Aldrich). The SPE materials used to extract nitrosamines from aqueous solutions 
consisted in Supelclean $^{\mathrm{TM}}$ prepacked coconut charcoal EPA 521 tubes, 2g/6ml, supplied from Supelco. A mixed standard containing haloacetonitriles (HANs), trichloronitromethane (TCNM) and haloketones (HKs) (EPA 551B Halogenated Volatiles Mix) and internal standard 1,2-dibromopropane were supplied from Supelco. All reagents not specified were obtained from Fisher Scientific.

\subsection{Preparation and analysis of chloramines}

Monochloramine $\left(\mathrm{NH}_{2} \mathrm{Cl}\right)$ stock solutions were prepared daily by slowly adding sodium hypochlorite $(\mathrm{NaOCl})$ into a rapidly stirred ammonium chloride $\left(\mathrm{NH}_{4} \mathrm{Cl}\right)$ solution adjusted to $\mathrm{pH}=8.5$ with sodium hydroxide, and using a $\mathrm{Cl}: \mathrm{N}$ molar ratio of at least 1:1.2 to avoid breakpoint chlorination resulting from local excess of hypochlorite (Mitch and Sedlak, 2002). Adjusting the $\mathrm{pH}$ at 8.5 minimizes the disproportionation of $\mathrm{NH}_{2} \mathrm{Cl}$ to dichloramine $\left(\mathrm{NHCl}_{2}\right)$, since $\mathrm{NHCl}_{2}$ forms at $\mathrm{pH}<8$ (U.S.

Environmental Protection Agency, 1999) according to the equilibrium:

$2 \mathrm{NH}_{2} \mathrm{Cl}+\mathrm{H}^{+}=\mathrm{NHCl}_{2}+\mathrm{NH}_{4}^{+}(1)$

Free chlorine and total chlorine concentrations in the stock solutions of sodium hypochlorite were determined iodometrically with sodium thiosulfate $0.1 \mathrm{M}$ (Prolabo, $>99.9 \%$ ). Initial $\mathrm{NH}_{2} \mathrm{Cl}_{\text {and }} \mathrm{NHCl}_{2}$ concentrations were determined by spectrophotometric measurement using their respective molar extinction coefficients at $245 \mathrm{~nm}$ and $295 \mathrm{~nm}$ and solving simultaneous equations (Schreiber and Mitch, 2005). Residual chloramines were analyzed iodometrically (Eaton et al., 1995).

\subsection{Chloramination experiments}

All glassware used during these experiments was washed with deionized water and baked at $500{ }^{\circ} \mathrm{C}$ for at least 5 hours prior to use. Reactions were conducted in sealed $1 \mathrm{~L}$ amber glass bottles at $20{ }^{\circ} \mathrm{C}$ in a temperature-controlled room, under dark conditions to avoid photolysis of NDMA. Chloramination experiments were conducted following the approach of Mitch et al. (Mitch et al., 2003), using high 
concentrations of $\mathrm{NH}_{2} \mathrm{Cl}$ (200 to $300 \mathrm{mg} / \mathrm{L}$ as $\mathrm{Cl}_{2}$ ) and a reaction time of 5 days for most of our

170 experiments. $\mathrm{NH}_{2} \mathrm{Cl}$ remained in excess during all the reaction time. Solutions were prepared by

171 dissolving a pre-determined amount of compound in $1 \mathrm{~L}$ of $10 \mathrm{mM}$ acetate, phosphate or carbonate

172 buffer. $100 \mathrm{~mL}$ of preformed monochloramine was then added to the working solution. Chloramination

173 experiments were conducted in triplicate. All series of experiments were completed with the

174 chloramination of a corresponding blank solution.

175 At given contact times, $350 \mathrm{~mL}$ of samples were transferred for residual chlorine, HANs and AOX

176 analyses, and $750 \mathrm{~mL}$ were processed for nitrosamines analyses.

177 Percent molar yields were calculated using the initial molar concentration of the studied compounds, 178 following Equation 2.

179

DBP yield $(\%)=\frac{[\mathrm{DBP}](\mathrm{nM})}{[\text { Organic compound }]_{0}(\mathrm{nM})} \times 100$

181 AOX formation rates were calculated as follows:

AOX formation rate $(\mathrm{mol} / \mathrm{mol})=\frac{[\mathrm{AOX}](\mu \mathrm{g} / \mathrm{L} \text { as } \mathrm{Cl}) / 35.5}{[\text { Organic compound }]_{0}(\mu \mathrm{M})}$

183

\subsection{Influence of dissolved $\mathrm{O}_{2}$}

Experiments were performed in saturated dissolved $\mathrm{O}_{2}$ solution and in absence of oxygen. The removal of oxygen was operated prior to chloramination by bubbling nitrogen gas through a Teflon line until dissolved $\mathrm{O}_{2}$ concentration was less than $0.3 \mathrm{mg} \mathrm{O} / \mathrm{L}$. The dissolved $\mathrm{O}_{2}$ concentration was monitored using a WTW Oxi 330 oxygen meter. The samples were continuously bubbled until the end of the experiment ( $2 \mathrm{~h}$ contact time). Previous experiments were conducted with NDMA standard solutions in 
order to verify that nitrogen bubbling for 2 hours did not lead to any significant NDMA or chlorinated

191 DBPs stripping.

192

193

194

195

196

197

198

199

200

201

202

203

204

205

206

207

208

209

210

211

212

\subsection{Analytical methods}

\subsubsection{Nitrosamines analysis}

NDMA analysis was performed according to the US EPA method (U.S. Environmental Protection Agency, 2004), consisting in a solid-phase extraction (SPE) using coconut charcoal EPA 521 tubes

followed by GC/MS analysis in EI mode. Analytical details are provided elsewhere (Le Roux et al., 2010) and summarized below. Chloramination reactions were quenched using $2.5 \mathrm{~g}$ sodium sulfite before SPE. Unlike previous studies (Chen and Young, 2009; Schreiber and Mitch, 2006), no ascorbic acid was used because it was found to degrade into furfural during SPE in coconut charcoal tubes, which led to poor NDMA recovery. Prior to the extraction, $200 \mathrm{ng}$ of NDMA-d6 was added to each $1 \mathrm{~L}$ sample as an internal standard. Each sample was extracted at a continuous flow rate through the SPE tube. Analytes were eluted from the SPE bed with $15 \mathrm{~mL}$ of methylene chloride. Extracts were then filtered through $5 \mathrm{~g}$ anhydrous sodium sulfate column to remove residual water. Methylene chloride extracts were then concentrated down to $1 \mathrm{~mL}$ under a stream of $\mathrm{N}_{2}$, after addition of DPNA-d14 (200 ng) used as recovery standard. Samples extracts were analyzed immediately after SPE using a HP 6890 series gas chromatograph system coupled with a HP 5973 mass selective detector (MSD) in electron impact (EI) mode. Samples were injected in pulsed splitless mode using helium as the carrier gas. A Varian VF-5ms capillary column (30 m by $0.25 \mathrm{~mm}$ i.d. by $0.25 \mu \mathrm{m}$ film thickness) supplied through Interchim was used to separate the analytes. Quantitative analyses were performed in selectedion monitoring (SIM) mode. Full scan mode (40 - $240 \mathrm{~m} / \mathrm{z})$ analyses were also conducted for complementary spectral information. This method reached extraction efficiencies of approximately 
85\%. The method detection limit (MDL) for NDMA at the $99 \%$ confidence level was determined to be

$21433 \mathrm{ng} / \mathrm{L}$.

215

216

217

218

219

220

221

222

223

224

225

226

227

228

229

230

231

232

233

234

235

236

\subsubsection{HANs, HKs, TCNM and AOX analysis}

Chloramination reactions were stopped using $250 \mathrm{mg}$ ascorbic acid prior to HAN and AOX analysis to avoid HANs degradation occurring in the presence of excess sodium sulfite (Croue and Reckhow, 1989). HANs, HKs and TCNM analysis was based on the US EPA 551.1 method (Munch and Hautman, 1995). $50 \mathrm{~mL}$ of samples were transferred to amber glass bottles and 1,2-dibromopropane (100 $\mu \mathrm{g} / \mathrm{L})$ was added as an internal standard. Samples were extracted by shaking for 4 min into $3 \mathrm{~mL}$ MTBE. Extracts were analyzed using GC/MS (same equipment as used for nitrosamines analysis), along with HANs, HKs and TCNM calibration standards. $1 \mu \mathrm{L}$ was injected in pulsed splitless mode with an inlet temperature of $150{ }^{\circ} \mathrm{C}$. The column temperature program was $40{ }^{\circ} \mathrm{C}$ held for $3 \mathrm{~min}$, ramping to $55^{\circ} \mathrm{C}$ at $2{ }^{\circ} \mathrm{C} / \mathrm{min}$ and holding for $1 \mathrm{~min}$, then a ramp of $5{ }^{\circ} \mathrm{C} / \mathrm{min}$ to $85^{\circ} \mathrm{C}$, and a final ramp of $40{ }^{\circ} \mathrm{C} / \mathrm{min}$ to $200{ }^{\circ} \mathrm{C}$ held for $1 \mathrm{~min}$. The MDL for this method is about $0.1 \mu \mathrm{g} / \mathrm{L}$. AOX were determined using a Dohrmann DX 20 analyzer after adsorption onto activated carbon (European Standard EN 1485, 1996). The detection limit for this method is about $20 \mu \mathrm{g}$ as $\mathrm{Cl}^{-} / \mathrm{L}$.

\section{Results and discussion}

Figure 1 shows as example the kinetic results for AOX, DCAN and NDMA formation obtained with $3 \mu \mathrm{M}$ ranitidine and $2.5 \mathrm{mM} \mathrm{NH}_{2} \mathrm{Cl}$ at $\mathrm{pH} 8.5$. $\mathrm{NH}_{2} \mathrm{Cl}$ consumption over 120 hours was always about $50 \%$ of the initial concentration. Same results were obtained for the other investigated compounds. Results from control samples exhibited similar chloramine decay. Kinetic modeling performed using Copasi software and Jafvert and Valentine's model (Jafvert and Valentine, 1992) confirmed that monochloramine $\left(\mathrm{NH}_{2} \mathrm{Cl}\right)$ predominantly decays by self-disproportionation under our experimental conditions ( $\mathrm{pH} 8.5,10 \mathrm{mM}$ phosphate buffer). Hence, the consumption of $\mathrm{NH}_{2} \mathrm{Cl}$ by the model 
compounds investigated was insignificant and could not be quantified. AOX formation leveled off after only $2 \mathrm{~h}$ contact time, whereas NDMA and DCAN formation were slower and reached their maximum after $24 \mathrm{~h}$. This observation is in accordance with results from the chlorination of proteins (one of the most important precursors of DCAN in drinking waters), that shows a two-step process (Reckhow, 241 2001). First, rapid reactions with reactive sites form THMs and Total Organic Halides (TOX) (Hureiki 242 et al., 1994), then slow degradation of proteins leads to DCAN formation. A similar behavior for DBPs 243 formation kinetics could occur during the chloramination of ranitidine.

The formation of NDMA, HANs and $\mathrm{AOX}$ at $\mathrm{pH} 8.5$ from selected compounds was monitored after 5 days of contact time (Table 1). Ranitidine exhibited the highest molar yield with 40.2\% NDMA formed. Similar amounts of NDMA were produced after 5 days of contact time for initial monochloramine concentrations of $0.5 \mathrm{mM}$ to $2.5 \mathrm{mM}$ and $100 \mathrm{nM}$ ranitidine solutions i.e. for large excess of monochloramine. Yields for the other pharmaceuticals ranged from 0.4 to $8.2 \%$ and less than $0.4 \%$ for diuron and isoproturon. NDMA formation from DMA is known to be $<3 \%$ molar conversion (Schmidt et al., 2006; Schreiber and Mitch, 2006) Minocycline and especially ranitidine exhibited higher molar yields than other tertiary amines or DMA.

253 Compounds presenting heterocyclic ring in their structure (e.g. furan in ranitidine) produced more 254 NDMA than compounds with DMA functions near carbonyl groups (i.e. diuron and isoproturon) 255 (Schmidt et al., 2006) and compounds with aromatic rings (e.g. minocycline or mifepristone). According to Shen and Andrews (2011), the higher yield observed for ranitidine would be explained by the electron-donating effect of furan group that increases electron density on the nitrogen atom and thus 258 enhance electrophilic substitution of chlorine atom. This mechanism would involve the formation of 259 dimethylchloramine (DMCA), DMA and then NDMA (Mitch and Sedlak, 2004). However, the presence 260 of DMA as a key intermediate could not explain the high yield obtained with ranitidine because the 
261 NDMA yields from DMA are always $<3 \%$ in literature. An alternative mechanism would involve the 262 nucleophilic substitution of $\mathrm{NH}_{2} \mathrm{Cl}$ on nitrogen atom instead of electrophilic substitution (i.e. chlorine 263 transfer with formation of a DMCA group). Further research is needed to fully address the formation 264 mechanism of NDMA from dimethylaminomethylfuran group.

265 As suggested by (Shen et Andrews, 2011), ranitidine can be considered as a significant NDMA 266 precursor because 6 to $39 \%$ of ranitidine is excreted as the parent form by human body $(\mathrm{Jjemba}, 2006)$ 267 and its metabolites maintain the furan and DMA groups in their structures. Moreover, the removal of 268 ranitidine through WWTP can be relatively low (Castiglioni et al., 2006). The presence of ranitidine and 269 its metabolites in wastewaters could contribute significantly to the high NDMA formation potentials 270 observed at several WWTP, which are much higher than concentrations predicted based upon DMA 271 concentrations in raw waters and calculated following previously proposed formation mechanisms 272 (Mitch and Sedlak, 2004; Mitch et al., 2003).

273 Minocycline, the second highest NDMA precursor of the pool of compounds studied (8.2\% NDMA 274 molar conversion) contains two dimethylamine functional groups that probably partly explain the 275 significant formation of NDMA. Amitriptyline and doxepin have similar molecular structures and 276 formed 1.15 and $2.32 \%$ of NDMA, respectively. The three carbon atoms between the DMA group and 277 the three rings could explain their lower reactivity compared to ranitidine (Shen and Andrews, 2011). 278 The presence of the oxygen atom in doxepin would explain the higher yield of NDMA for this molecule 279 compared to amitriptyline. Chloramination of trifluralin led to the formation of $0.18 \%$ DPNA, half the 280 formation of NDMA obtained from mifepristone that also incorporates an aromatic ring substituted with 281 a dialkylamine group. The lower yield for trifluralin can be attributed to the electron withdrawing effect 282 of the two nitro groups. The electron withdrawing effect of the carbonyl group would also explain the 283 low formation yield of NDMA from isoproturon and diuron (Schmidt et al., 2006). 
In full scan mode, the GC/MS chromatogram of the extracts revealed the presence of

dimethylformamide (DMF) and dimethylcyanamide (DMC) as by-products of the reaction of monochloramine with diuron or ranitidine. These compounds are known to be UDMH oxidation products, as well as NDMA (Mitch and Sedlak, 2002). However, formation mechanisms of DMC and DMF remain unclear. No other nitrosamine was detected during the experiments with compounds containing dimethylamine functional groups.

Ranitidine formed about 10 times less DCAN than NDMA (Table 1). Minocycline was the second

highest DCAN precursor (1.5\% DCAN yield). For the other compounds studied, the amounts of DCAN formed were quite similar to those of NDMA ( $<1 \%$ yield). No TCAN formation was detected during these experiments. No correlation could be made between NDMA formation and DCAN formation but more DCAN was generally formed when NDMA was produced in higher amounts. Minocycline exhibited the highest AOX formation rate $(8.98 \mathrm{~mol} / \mathrm{mol})$, which could be related to its highly aromatic and oxygen-containing structure. Ranitidine was the second AOX precursor with $0.95 \mathrm{~mol} / \mathrm{mol}$ formation rate. The other compounds investigated did not lead to any significant AOX formation in our experimental conditions. These results indicate that compounds producing high amount of NDMA tend 300 also to form more of other DBPs (AOX, and especially DCAN).

\subsection{Influence of Nitrites}

303 Previous research (Choi and Valentine, 2003) proposed an "enhanced nitrosation pathway" describing 304 NDMA formation from the reaction of DMA with nitrite and hypochlorite. Nitrites were also found to 305 enhance the formation of NDMA during the chlorination of diuron (Chen and Young, 2009). Because 306 low amount of free chlorine may be present in monochloramine solution, nitrites could contribute to the 307 formation of NDMA by chloramination. Experiments conducted with $1 \mu \mathrm{M}$ amitriptyline and $1 \mu \mathrm{M}$ 
mifepristone showed that NDMA formation was not significantly different in presence and in absence of

$3091 \mu \mathrm{M}$ nitrites (Table 2). These results indicate that the formation of NDMA from tertiary amines during 310 chloramination is not enhanced by any nitrosation mechanism, which could have occurred in presence 311 of free chlorine and nitrites.

\subsection{Effect of $\mathrm{pH}$}

314 To assess the influence of $\mathrm{pH}$ on the formation of $\mathrm{DBPs}, \mathrm{NH}_{2} \mathrm{Cl}(2.5 \mathrm{mM})$ was applied to ranitidine 315 solutions $(3 \mu \mathrm{M})$ in deionized water buffered at $\mathrm{pH}$ ranging from 4 to 10 (Table 3). NDMA, HANs, 316 HKs, and TCNM were analyzed after a contact time of 5 days. NDMA formation from chloramination 317 of ranitidine exhibited a maximum (59.6\% yield) at $\mathrm{pH} 7.9$, which is similar to $62.9 \%$ reported in 318 Schmidt et al. (2006) for the same conditions. Amitriptyline and mifepristone followed similar trends, 319 forming much less NDMA at $\mathrm{pH} 10$ than at $\mathrm{pH} 8$ (Table 2). Other studies showed that NDMA 320 formation from chloramination of DMA or diuron varied with $\mathrm{pH}$ with a maximum formation rate 321 between pH 7 and 9 (Chen and Young, 2008; Mitch and Sedlak, 2002; Schreiber and Mitch, 2006). 322 Self-decomposition and hydrolysis of $\mathrm{NH}_{2} \mathrm{Cl}$ at $\mathrm{pH}<8$ are known to lead to the formation of $\mathrm{NHCl}_{2}$ 323 (Valentine and Jafvert, 1988). Because $\mathrm{NHCl}_{2}$ is known to enhance NDMA formation (Schreiber and 324 Mitch, 2006), then acid-catalyzed disproportionation of $\mathrm{NH}_{2} \mathrm{Cl}$ into $\mathrm{NHCl}_{2}$ could explain the higher 325 formation of NDMA at $\mathrm{pH} 7.9$ compared to $\mathrm{pH}>8$. However, kinetic modeling of $\mathrm{NH}_{2} \mathrm{Cl}$ 326 decomposition indicates that $\mathrm{NHCl}_{2}$ is not present in important amounts at $\mathrm{pH}$ 7.9. Furthermore, NDMA 327 formation from ranitidine at $\mathrm{pH}$ where $\mathrm{NHCl}_{2}$ is the major specie (i.e. $\mathrm{pH} \sim 4$ ) was much lower than at $328 \mathrm{pH} 8$, indicating that other factors than chloramines speciation may play a role in NDMA formation 329 mechanisms. Thus, ranitidine acid-base equilibrium $(\mathrm{pKa}=8.2)$ could explain the decrease of NDMA 330 formation when the protonated form of ranitidine decreases at $\mathrm{pH}>8$ (Figure 2). At $\mathrm{pH}<8$, NDMA 
331 formation seems to be strongly dependent on the $\mathrm{NH}_{2} \mathrm{Cl}$ concentration in the solution, and was not

332 enhanced by the presence of $\mathrm{NHCl}_{2}$.

333 As shown in Table 3, important amounts of trichloronitromethane (TCNM) were formed from ranitidine 334 at acidic $\mathrm{pH}(12.57 \%$ at $\mathrm{pH}$ 4). The amounts of TCNM formed decreased as the $\mathrm{pH}$ was raised from $335 \mathrm{pH} 4$ to $\mathrm{pH} 10$, but were still higher than other chlorinated DBPs at neutral and basic $\mathrm{pH}$. Whereas 336 NDMA formation was maximum around pH 8, DCAN, 1,1-DCP and 1,1,1-TCP exhibited a maximum 337 formation yield at $\mathrm{pH}$ 7. Moreover, TCAN formation from ranitidine was low and relatively constant 338 when varying $\mathrm{pH}$ from 4 to 10 . The lower concentrations of DCAN and 1,1-DCP at $\mathrm{pH}>7 \mathrm{can}$ be 339 explained by base-catalyzed decomposition (Croue and Reckhow, 1989; Reckhow, 2001; Yang et al., 340 2007).

341 AOX formation was constant from $\mathrm{pH} 4$ to 7 and then decreased at alkaline $\mathrm{pH}$ (Table 3). As shown in 342 Figure 3, analyzed DBPs represent only a few percent of the AOX formed. TCNM accounts for $20 \%$ of 343 the produced $\mathrm{AOX}$ at $\mathrm{pH}$ 4. However, the proportion of identified DBPs is decreasing when increasing $344 \mathrm{pH}$.

\subsection{Influence of dichloramine}

To evaluate the influence of $\mathrm{NHCl}_{2}$ on $\mathrm{NDMA}$ formation from ranitidine, preformed $\mathrm{NHCl}_{2}$ or $\mathrm{NH}_{2} \mathrm{Cl}$

348 (1 mM) were applied to ranitidine solutions. Previous research indicated that NDMA formation from

349 DMA and $\mathrm{NHCl}_{2}$ was much higher than in the presence of $\mathrm{NH}_{2} \mathrm{Cl}$ (Schreiber and Mitch, 2006). Our

350 results showed that NDMA formation from $100 \mathrm{nM}$ ranitidine buffered at $\mathrm{pH} 8$ and after $24 \mathrm{~h}$ was

351 significantly lower with $\mathrm{NHCl}_{2}$ than with $\mathrm{NH}_{2} \mathrm{Cl}$ (46.8\% and $80.2 \%$ molar yields respectively, 352 Figure 4).

353 Total chlorine decay during our experiments with $\mathrm{NHCl}_{2}$ was about $85 \%$ after 24 hours, while it was 354 only $25 \%$ with $\mathrm{NH}_{2} \mathrm{Cl}$. Thus, $\mathrm{NHCl}_{2}$ decomposition is more rapid than $\mathrm{NH}_{2} \mathrm{Cl}$ at $\mathrm{pH}$ around $\mathrm{pH} 8$, which 
could explain why less NDMA was formed in presence of $\mathrm{NHCl}_{2}$. The autodecomposition of $\mathrm{NHCl}_{2}$ in our experiments could be well simulated by the kinetic model of Jafvert and Valentine (1992). According to this model, the hydrolysis of dichloramine (Equation 4) and inverse dismutation (Equation 5) lead to the formation of significant amounts of monochloramine.

$\mathrm{NHCl}_{2}+\mathrm{H}_{2} \mathrm{O} \rightarrow \mathrm{NH}_{2} \mathrm{Cl}+\mathrm{HOCl}$

$\mathrm{NHCl}_{2}+\mathrm{NH}_{3}+\mathrm{H}^{+} \rightarrow 2 \mathrm{NH}_{2} \mathrm{Cl}+\mathrm{H}^{+}$

The use of the model showed that the residual chlorine concentrations of $0.3 \mathrm{mM}$ analyzed after $24 \mathrm{~h}$ of contact time could be explained by the formation of $\mathrm{NH}_{2} \mathrm{Cl}$ from $\mathrm{NHCl}_{2}$ decomposition, which is almost complete after $24 \mathrm{~h}$. In this condition, the simulated $\mathrm{NH}_{2} \mathrm{Cl}$ exposure (i.e. the C.t value) represents about $38 \%$ of the $\mathrm{NH}_{2} \mathrm{Cl}$ exposure from direct $\mathrm{NH}_{2} \mathrm{Cl}$ addition. Thus, $\mathrm{NH}_{2} \mathrm{Cl}$ formed from the decomposition of $\mathrm{NHCl}_{2}$ could explain the amounts of NDMA formed during the chloramination of ranitidine using dichloramine. These results seem to indicate that dichloramine would not be involved into the formation of NDMA from ranitidine. No significant differences were observed for DCAN formation after the application of either $\mathrm{NH}_{2} \mathrm{Cl}$ or $\mathrm{NHCl}_{2}$ to $100 \mathrm{nM}$ ranitidine at $\mathrm{pH} 8$ (Figure 4).

\subsection{Influence of dissolved oxygen}

It has been demonstrated that dissolved oxygen concentration plays a major role in the formation of NDMA by chloramination of DMA (Schreiber and Mitch, 2006). Moreover, a recent study showed that the formation of NDMA from DMA could be catalyzed by activated carbon, and that the presence of oxygen was a critical factor in this mechanism (Padhye et al., 2010).

In order to assess whether or not dissolved oxygen would influence the formation of NDMA from the chloramination of other model compounds, $2.7 \mathrm{mM} \mathrm{NH}_{2} \mathrm{Cl}$ was applied to $3 \mu \mathrm{M}$ ranitidine during $2 \mathrm{~h}$ in presence and in absence of dissolved $\mathrm{O}_{2}$. NDMA formation was significantly inhibited for low oxygen 
concentration $\left(\sim 0.2 \mathrm{mg} \mathrm{O}_{2} / \mathrm{L}\right)$ compared to ambient $\mathrm{O}_{2}$ concentration $(\sim 9 \mathrm{mg} \mathrm{O} / \mathrm{L})$ (molar yields of $4.01 \%$ and $54 \%$ respectively, Figure 5a).

380 Dissolved $\mathrm{O}_{2}$ concentration did not affect AOX formation as much as NDMA formation (Figure 5b).

381 Moreover, DCAN formation was not influenced by dissolved $\mathrm{O}_{2}$ concentration while the formation of 382 other halogenated DBPs containing oxygen atoms (nitro or ketones functional groups, i.e. TCNM, 383 1,1-DCP and 1,1,1-TCP) was approximately an order of magnitude lower in the presence of $0.2 \mathrm{mg} \mathrm{O}_{2} / \mathrm{L}$ (Figure 6). This indicates that dissolved oxygen could be incorporated into those DBPs, i.e. an oxygen atom of dissolved oxygen could serve as a source for the oxygen atom in nitroso or ketone functions of DBPs. Further research with model compounds and using inhibitors of oxygen species need to be done to elucidate the mechanisms involved into the formation of NDMA and to understand the role of dissolved oxygen.

\section{Conclusion}

- Even if concentrations of compounds used for our study were relatively high and are not likely to be found in natural waters, we observed that several nitrogenous anthropic compounds can lead to important concentrations of N-DBPs including NDMA, DCAN, 1,1-DCP, or TCNM. From the seven compounds investigated in our study, four compounds contain dimethylamine functional groups and exhibited yields higher than 1.15\% (ranitidine, minocycline, doxepin, amitriptyline). Especially, the pharmaceutical ranitidine is of great concern regarding its high molar yield into NDMA ( $60 \%$ at $\mathrm{pH} 7.9)$, as shown in earlier studies.

- Such differences in NDMA formation can not be explained by the release of DMA and the reactions of DMA with chloramines. More simple compounds than those described in the present work need to be studied to improve our understanding of molecular structure influence on the formation of NDMA. 
- Our results demonstrate that the reaction of $\mathrm{NHCl}_{2}$ with ranitidine would not form more NDMA than $\mathrm{NH}_{2} \mathrm{Cl}$. However, we confirmed the implication of dissolved oxygen in NDMA formation mechanisms. Dissolved oxygen was found to play a role into the formation of other oxygen-containing DBPs (TCNM, 1,1-DCP and 1,1,1-TCP) but did not influence DCAN formation. These results need further investigation to better understand the incorporation of dissolved oxygen into DBPs.

- Considering the high conversion of ranitidine to NDMA, the use of chloramination as a disinfection for wastewaters containing ranitidine can lead to the formation of important amounts of NDMA. This could explain the high NDMA formation potentials observed at several WWTP, which are much higher than concentrations predicted based upon DMA concentrations in raw waters.

416 We would like to thank the French Ministry of Higher Education and Research (Ministère de 417 l'Enseignement Supérieur et de la Recherche) for its financial support. 


\section{References}

428 Castiglioni, S., Bagnati, R., Fanelli, R., Pomati, F., Calamari, D., Zuccato, E., 2006. Removal of 429 Pharmaceuticals in Sewage Treatment Plants in Italy. Environ. Sci. Technol. 40 (1), 357-363.

430 Chen, W., Young, T.M., 2008. NDMA formation during chlorination and chloramination of aqueous 431 diuron solutions. Environ. Sci. Technol. 42 (4), 1072-1077.

432 Chen, W., Young, T.M., 2009. Influence of nitrogen source on NDMA formation during chlorination of 433 diuron. Water Res. 43 (12), 3047-3056.

434 Choi, J., Duirk, S.E., Valentine, R.L., 2002. Mechanistic studies of N-nitrosodimethylamine-(NDMA) 435 formation in chlorinated drinking water. J. Environ. Monit. 4 (2), 249-252.

436 Choi, J., Valentine, R.L., 2002. A kinetic model of N-nitrosodimethylamine (NDMA) formation during 437 water chlorination/chloramination. Water Sci. Technol. 46 (3), 65-71.

438 Choi, J., Valentine, R.L., 2002. Formation of N-nitrosodimethylamine (NDMA) from reaction of 439 monochloramine: A new disinfection by-product. Water Res. 36 (4), 817-824.

440 Choi, J., Valentine, R.L., 2003. N-Nitrosodimethylamine Formation by Free-Chlorine-Enhanced 441 Nitrosation of Dimethylamine. Environ. Sci. Technol. 37 (21), 4871-4876.

442 Croue, J.P., Reckhow, D.A., 1989. Destruction of chlorination byproducts with sulfite. ESandT 443 Contents $23(11), 1412-1419$. 
444 Eaton, A.D., Clesceri, L.S., Greenberg, A.E., Eds. Standard Methods for the Examination of Water and

445 Wastewater, 19th ed; American Public Health Association/American Water Works Association/Water

446 Environment Federation Publishers; Washington D.C., USA, 1995.

447 European Standard EN 1485 (1996) Water Quality Determination of Adsorbable Organically Bound 448 Halogens (AOX).

449 Gerecke, A.C., Sedlak, D.L., 2003. Precursors of N-nitrosodimethylamine in natural waters. Environ. $450 \quad$ Sci. Technol. 37 (7), 1331-1336.

451 Hoigne, J., Bader, H., 1988. The formation of trichloronitromethane (chloropicrin) and chloroform in a 452 combined ozonation/chlorination treatment of drinking water. Water Res. 22 (3), 313-319.

453 Hureiki, L., Croué, J., Legube, B., 1994. Chlorination studies of free and combined amino acids. Water 454 Res. 28 (12), 2521-2531.

455 Jafvert, C.T., Valentine, R.L., 1992. Reaction scheme for the chlorination of ammoniacal water.

456 Environ. Sci. Technol. 26 (3), 577-786.

457 Jjemba, P.K., 2006. Excretion and ecotoxicity of pharmaceutical and personal care products in the 458 environment. Ecotoxicol. Environ. Saf. 63 (1), 113-130.

459 Joo, S.H., Mitch, W.A., 2007. Nitrile, Aldehyde, and Halonitroalkane Formation during

460 Chlorination/Chloramination of Primary Amines. Environmental Science \& Technology 41 (4), 1288$461 \quad 1296$. 
462 Kolpin, D.W., Furlong, E.T., Meyer, M.T., Thurman, E.M., Zaugg, S.D., Barber, L.B., Buxton, H.T., 463 2002. Pharmaceuticals, Hormones, and Other Organic Wastewater Contaminants in U.S. Streams, 464 1999-2000: A National Reconnaissance. Environmental Science \& Technology 36 (6), 1202-1211.

465 Le Roux, J., Gallard, H., Croue, J.P., 2010. Formation of NDMA by Chloramination of Nitrogenous 466 Pharmaceuticals. Water Practice \& Technology 5 (4).

467 Mitch, W.A., Gerecke, A.C., Sedlak, D.L., 2003. A N-Nitrosodimethylamine (NDMA) precursor 468 analysis for chlorination of water and wastewater. Water Res. 37 (15), 3733-3741.

469 Mitch, W.A., Sedlak, D.L., 2002. Formation of N-nitrosodimethylamine (NDMA) from dimethylamine 470 during chlorination. Environ. Sci. Technol. 36 (4), 588-595.

471 Mitch, W.A., Sedlak, D.L., 2004. Characterization and Fate of N-Nitrosodimethylamine Precursors in 472 Municipal Wastewater Treatment Plants. Environ. Sci. Technol. 38 (5), 1445-1454.

473 Muellner, M.G., Wagner, E.D., Mccalla, K., Richardson, S.D., Woo, Y., Plewa, M.J., 2007. 474 Haloacetonitriles vs. regulated haloacetic acids: Are nitrogen-containing DBPs more toxic? Environ. 475 Sci. Technol. 41 (2), 645-651.

476 Munch, D.J., Hautman, D.P. (1995) EPA Method 551.1 Determination of chlorination disinfection 477 byproducts, chlorinated solvents, and halogenated pesticides/herbicides in drinking water by liquid478 liquid extraction and gas chromatography with electron-capture detection, revision 1.0. Available online 479 from http://www.epa.gov/sam/pdfs/EPA-551.1.pdf, accessed April 22, 2009.

480 National Cancer Institute (1978) Bioassay of chloropicrin for possible carcinogenicity (CAS No. 76-06481 2). National Toxicology Program Carcinogenesis Technical Report Series, U.S. Department of Health 482 and Human. 
483 Padhye, L., Wang, P., Karanfil, T., Huang, C., 2010. Unexpected role of activated carbon in promoting 484 transformation of secondary amines to N -nitrosamines. Environ. Sci. Technol. 44 (11), 4161-4168.

485 Plewa, M.J., Wagner, E.D., Jazwierska, P., Richardson, S.D., Chen, P.H., McKague, A.B., 2004. 486 Halonitromethane drinking water disinfection byproducts: Chemical characterization and mammalian 487 cell cytotoxicity and genotoxicity. Environ. Sci. Technol. 38 (1), 62-68.

488 Radjenovic, J., Petrovic, M., Barceló, D., 2009. Fate and distribution of pharmaceuticals in wastewater 489 and sewage sludge of the conventional activated sludge (CAS) and advanced membrane bioreactor 490 (MBR) treatment. Water Res. 43 (3), 831-841.

491 Reckhow, D.A., MacNeill, A.L., Platt, T.L., MacNeill, A.L., McClellan, J.N., 2001. Formation and 492 degradation of dichloroacetonitrile in drinking waters. J. Water Supply Res. Technol. AQUA 50 (1), 149313.

494 Schmidt, C.K., Sacher, F., Brauch, H. (2006) Strategies for minimizing formation of NDMA and other 495 nitrosamines during disinfection of drinking water. Proceedings of the American Water Works 496 Association Water Quality Technology Conference, Denver, CO.

497 Schneider, M., Quistad, G.B., Casida, J.E., 1999. Glutathione activation of chloropicrin in the 498 Salmonella mutagenicity test. Mutation Research/Genetic Toxicology and Environmental Mutagenesis $499439(2), 233-238$.

500 Schreiber, I.M., Mitch, W.A., 2005. Influence of the order of reagent addition on NDMA formation 501 during chloramination. Environ. Sci. Technol. 39 (10), 3811-3818.

502 Schreiber, I.M., Mitch, W.A., 2006. Nitrosamine formation pathway revisited: The importance of 503 chloramine speciation and dissolved oxygen. Environ. Sci. Technol. 40 (19), 6007-6014. 
504 Shen, R., Andrews, S., 2011. Demonstration of 20 pharmaceuticals and personal care products (PPCPs)

505 as nitrosamine precursors during chloramine disinfection. Water Res. 45 (2), 944-952.

506 Thibaud, H., de Laat, J., Merlet, N., Doré, M., 1987. Chloropicrin formation in aqueous solution: Effect

507 of nitrites on precursors formation during the oxidation of organic compounds (Formation de

508 chloropicrine en milieu aqueux: Influence des nitrites sur la formation de precurseurs par oxydation de

509 composes organiques). Water Res. 21 (7), 813-821.

510 U.S. Environmental Protection Agency (1987) Integrated Risk Information System (IRIS), N-

511 nitrosodimethylamine. Office of Research and Development (ORD), National Center for Environmental

512 Assessment. Available online from www.epa.gov/iris/subst/0045.htm, accessed October 20, 2008.

513 U.S. Environmental Protection Agency (1999) Alternative disinfectants and oxidants. EPA guidance 514 manual. Available online from

515 http://www.epa.gov/OGWDW/mdbp/alternative_disinfectants_guidance.pdf, accessed April 10, 2009.

516 U.S. Environmental Protection Agency (2004) Method 521: determination of nitrosamines in drinking

517 water by solid phase extraction and capillary column gas chromatography with large volume injection

518 and chemical ionization tandem mass spectrometry (MS/MS). EPA/600/R-05/054. Available online

519 from http://www.epa.gov/nerlcwww/m_521.pdf, accessed October 20, 2008.

520 Valentine, R.L., Jafvert, C.T., 1988. General acid catalysis of monochloramine disproportionation.

521 Environmental Science \& Technology 22 (6), 691-696.

522 Yang, X., Shang, C., Westerhoff, P., 2007. Factors affecting formation of haloacetonitriles, haloketones, 523 chloropicrin and cyanogen halides during chloramination. Water Res. 41 (6), 1193-1200. 
524 Zuccato, E., Calamari, D., Natangelo, M., Fanelli, R., 2000. Presence of therapeutic drugs in the 525 environment. The Lancet 355 (9217), 1789-1790.

526

527

528

529

530

531

532

533

534

535

536

537

538

539

540

541

542

543

544

545

546 
$547 \quad$ Tables

548 Table 1. Nitrosamine and DCAN formation from compounds investigated at $\mathrm{pH} 8.5$ (5 days contact 549 time)

\begin{tabular}{|c|c|c|c|c|c|c|}
\hline \multirow[b]{2}{*}{$\begin{array}{l}\text { Compound } \\
\text { investigated }\end{array}$} & \multirow[b]{2}{*}{$\begin{array}{l}\text { Molecular } \\
\text { structure }\end{array}$} & \multirow{2}{*}{$\begin{array}{c}\text { Compound } \\
\text { concentration } \\
(\mathbf{n M})\end{array}$} & \multirow{2}{*}{$\begin{array}{c}\mathrm{NH}_{2} \mathrm{Cl} \\
\text { concentration }^{\mathrm{a}} \\
(\mathbf{m M})\end{array}$} & \multicolumn{2}{|c|}{$\begin{array}{c}\text { Molar yield } \\
\left(\text { SD }^{\mathbf{c}}\right)\end{array}$} & \multirow{2}{*}{$\begin{array}{c}\text { AOX } \\
\text { formation } \\
\text { rate }^{\mathrm{e}} \\
(\mathbf{m o l} / \mathbf{m o l}) \\
\left(\mathrm{SD}^{\mathbf{c}}\right)\end{array}$} \\
\hline & & & & Nitrosamine $^{d}$ & DCAN & \\
\hline Ranitidine & & 14760 & 4.0 & 40.2 (1.4) & $5.8(0.2)$ & $0.95(0.18)$ \\
\hline Minocycline & & 2820 & 2.5 & $8.2(0.7)$ & $1.5(0.1)$ & $8.98(0.89)$ \\
\hline Doxepin & & 1730 & 2.5 & $2.32(0.01)$ & $0.5(0.1)$ & N.D. \\
\hline Amitriptyline & & 3480 & 2.5 & $1.15(0.04)$ & $0.8(0.4)$ & N.D. \\
\hline Mifepristone & & 3170 & 2.5 & $0.39(0.02)$ & $0.2(0.1)$ & N.D. \\
\hline Isoproturon & & 5290 & 2.5 & $0.34 \quad(0.02)$ & N.D. & N.D. \\
\hline Trifluralin & & 810 & 2.5 & $0.18(0.01)$ & N.D. & N.D. \\
\hline Diuron & & 16560 & 4.0 & $0.15(0.01)$ & N.D. & N.D. \\
\hline $\begin{array}{l}\text { a Initial } \mathrm{NH}_{2} \mathrm{C} \\
10 \mathrm{mM} \text { phosp } \\
{ }^{\mathrm{b}} \text { Molar yields } \\
{ }^{\mathrm{c}} \mathrm{SD}=\text { Standa } \\
{ }^{\mathrm{d}} \text { Nitrosamine } \\
{ }^{\mathrm{e}} \text { AOX format } \\
\text { N.D. = Not D }\end{array}$ & $\begin{array}{l}\text { were calcula } \\
\mathrm{d} \text { Deviation } \\
\text { formed is ND } \\
\text { on rates expr } \\
\text { tected }\end{array}$ & $\begin{array}{l}\text { applied to a sol } \\
\text { [ 8.5) } \\
\text { d based upon th } \\
3 \text { replicates } \\
\text { MA except for tr } \\
\text { ssed as mol AOr }\end{array}$ & $\begin{array}{l}\text { tion containing a } \\
\text { initial compound } \\
\text { fluralin (DPNA) } \\
\text { as } \mathrm{Cl}^{-} / \mathrm{mol} \text { of in }\end{array}$ & $\begin{array}{l}\text { ompound invest } \\
\text { concentration } \\
\text { tial compound }\end{array}$ & ed in deic & d water with \\
\hline
\end{tabular}


550 Table 2. Effect of $\mathrm{pH}$ and $\mathrm{NO}_{2}{ }^{-}$on NDMA formation from amitriptyline and mifepristone over 5 days

551 with $10 \mathrm{mM}$ buffer (phosphate for $\mathrm{pH} 8.5$ and carbonate for $\mathrm{pH} 10$ ).

\begin{tabular}{|c|c|c|c|c|c|}
\hline Expt & Compound investigated & $\begin{array}{c}\text { Compound } \\
\text { concentration } \\
(\mu \mathrm{M})\end{array}$ & $\begin{array}{c}\mathrm{NH}_{2} \mathrm{Cl} \\
\text { concentration } \\
(\mathbf{m M})\end{array}$ & $\begin{array}{c}\text { NDMA yield } \\
(\%) \\
\left(\text { SD }^{\mathbf{b}}\right)\end{array}$ & pH \\
\hline \multirow[t]{4}{*}{1} & \multirow{2}{*}{ Amitriptyline } & 0.38 & 3.8 & 2.37 (0.34) & 8.5 \\
\hline & & 0.38 & 3.8 & $0.08 \quad(0.01)$ & 10 \\
\hline & \multirow{2}{*}{ Mifepristone } & 0.35 & 3.8 & $1.00(0.30)$ & 8.5 \\
\hline & & 0.35 & 3.8 & $0.04 \quad(0.01)$ & 10 \\
\hline \multirow[t]{4}{*}{2} & Amitriptyline & 1 & 3.4 & $1.93 \quad(0.15)$ & 8.5 \\
\hline & Amitriptyline $+1 \mu \mathrm{M} \mathrm{NO}_{2}^{-}$ & 1 & 3.4 & $1.72 \quad(0.15)$ & 8.5 \\
\hline & Mifepristone & 1 & 3.4 & $0.89 \quad(0.09)$ & 8.5 \\
\hline & Mifepristone $+1 \mu \mathrm{M} \mathrm{NO}_{2}^{-}$ & 1 & 3.4 & $0.97 \quad(0.09)$ & 8.5 \\
\hline $\begin{array}{l}{ }^{\mathrm{a}} \mathrm{Mol} \\
{ }^{\mathrm{b}} \mathrm{SD}=\end{array}$ & $\begin{array}{l}\text { ields were calculated based } \\
\text { tandard Deviation on } 3 \text { repli }\end{array}$ & $\begin{array}{l}\text { pon the initial } \\
\text { ites }\end{array}$ & mpound conce & tion & \\
\hline
\end{tabular}


560 Table 3. Effect of $\mathrm{pH}$ on NDMA and chlorinated DBPs formation from $3 \mu \mathrm{M}$ ranitidine and $2.5 \mathrm{mM}$

$561 \mathrm{NH}_{2} \mathrm{Cl}$ (5 days contact time).

\begin{tabular}{cccccccc}
\hline & \multicolumn{9}{c}{ Molar yield (\%) } & & $\begin{array}{c}\text { AOX } \\
\text { formation } \\
\text { fH }\end{array}$ & NDMA & DCAN & TCAN & TCNM & 1,1-DCP & 1,1,1-TCP & $\begin{array}{c}\text { rate } \\
\text { (mol/mol) }\end{array}$ \\
& & & & & & & \\
4 & 0.2 & 1.33 & 0.31 & 12.57 & N.D. & N.D. & 1.63 \\
5.5 & 20.6 & 1.08 & 0.49 & 6.14 & 1.06 & 0.38 & 1.63 \\
7 & 42.2 & 1.65 & 0.31 & 3.05 & 1.51 & 1.37 & 1.74 \\
7.9 & 59.6 & 0.81 & 0.28 & 1.43 & 0.24 & 0.03 & 1.31 \\
8.5 & 46.6 & 0.55 & 0.33 & 0.70 & 0.12 & N.D. & 1.07 \\
10 & 10.4 & 0.06 & 0.61 & 0.09 & N.D. & 0.02 & 0.56 \\
\hline
\end{tabular}

562

563

564

565

566

567

568

569

570

571

572

573

574

575

576

577 


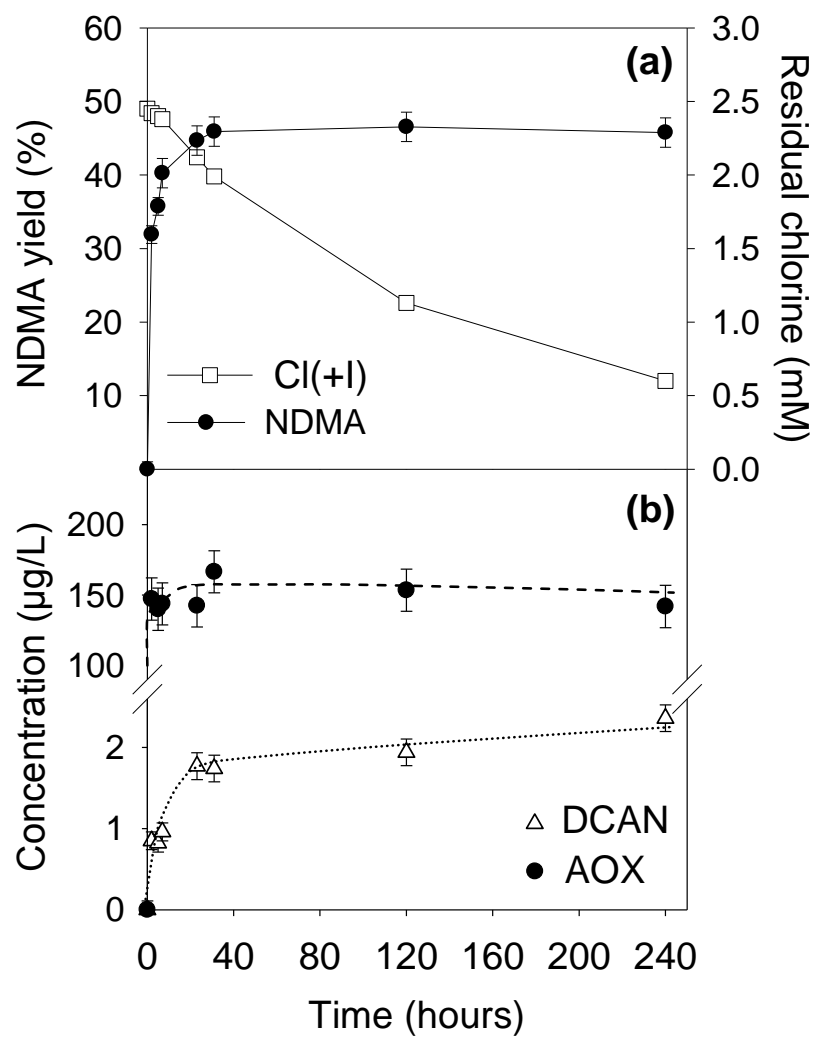

580 Figure 1. NDMA formation from $3 \mu \mathrm{M}$ ranitidine at $\mathrm{pH} 8.5$ with $10 \mathrm{mM}$ phosphate buffer, $2.5 \mathrm{mM}$ 581 monochloramine. Error bars represent one standard deviation $(n=3)$. NDMA molar yields were 582 calculated based upon the initial ranitidine concentration. 


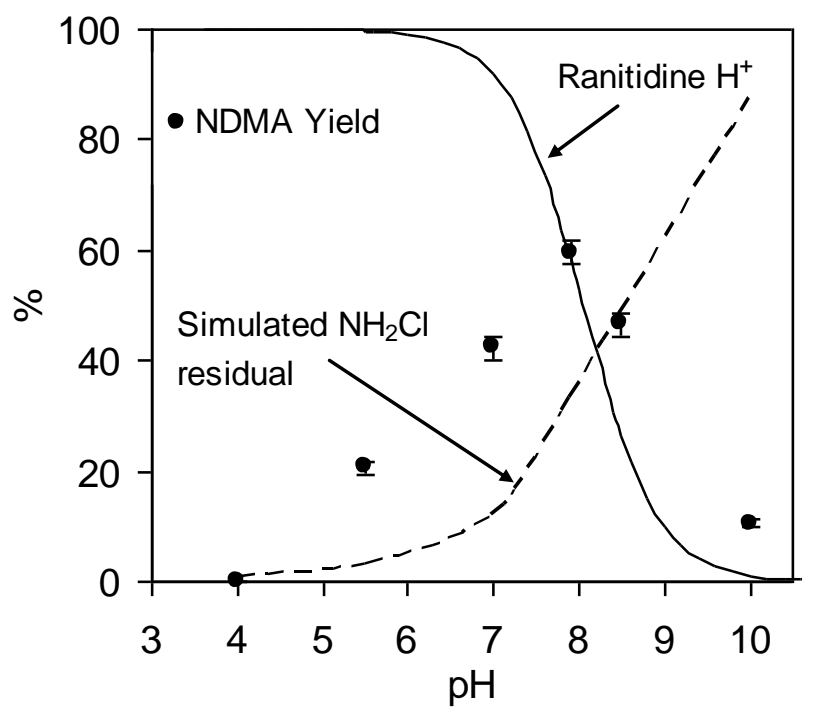

584

585 Figure 2. Effect of $\mathrm{pH}$ on NDMA formation from $3 \mu \mathrm{M}$ ranitidine and $2.5 \mathrm{mM}$ monochloramine over 5

586 days with $10 \mathrm{mM}$ buffer (acetate for $\mathrm{pH}$ 4.0-5.5, phosphate for $\mathrm{pH} 7.0-8.5$ and carbonate for $\mathrm{pH} 10$ ); and

$587 \quad \mathrm{NH}_{2} \mathrm{Cl}$ residuals calculated using Jafvert \& Valentine model (1992). NDMA yields were calculated

588 based on the initial ranitidine concentration; percentages of $\mathrm{NH}_{2} \mathrm{Cl}$ residuals were calculated based on 589 the initial $\mathrm{NH}_{2} \mathrm{Cl}$ concentration.

590

591

592

593 


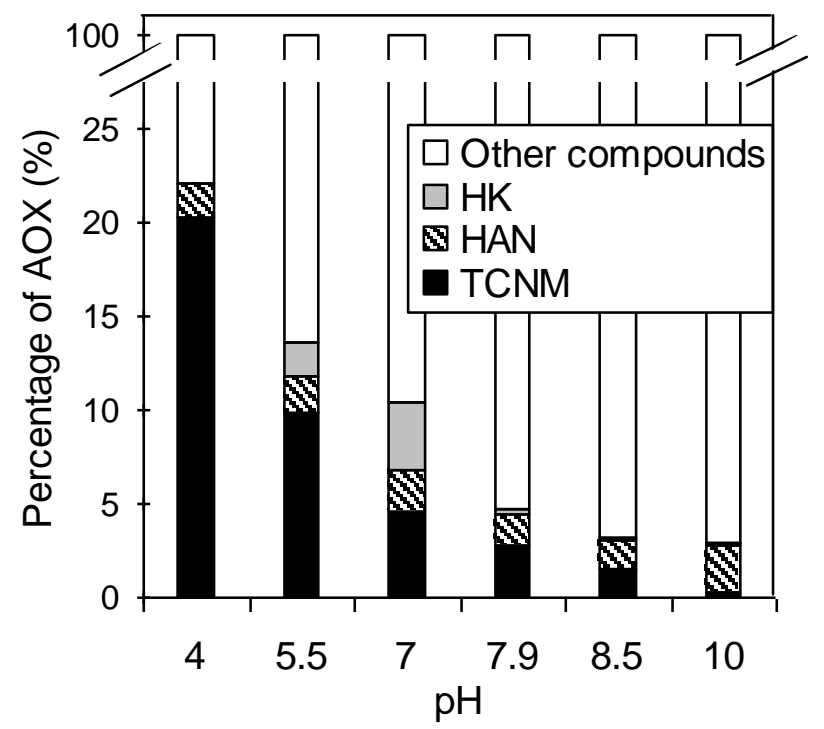

595 Figure 3. AOX repartition between trichloronitromethane (TCNM), haloacetonitriles (HAN: sum of 596 DCAN and TCAN) and haloketones (HK: sum of 1,1-DCP and 1,1,1-TCP) at different pH from $3 \mu \mathrm{M}$ 597 ranitidine and $2.5 \mathrm{mM} \mathrm{NH}_{2} \mathrm{Cl}$. Note the scale break.

598

599

600

601

602 


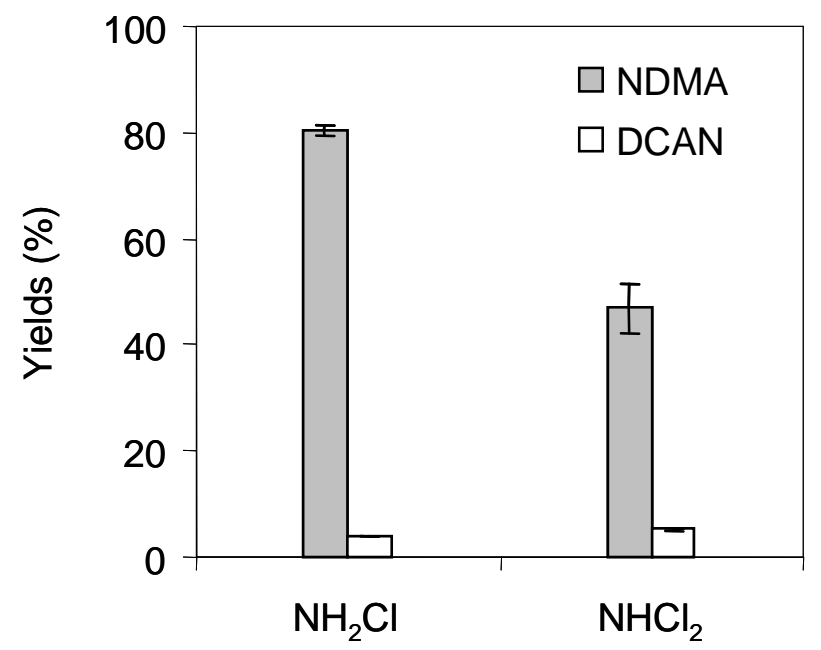

603

604 Figure 4. NDMA and DCAN formation after $24 \mathrm{~h}$ following the application of $1 \mathrm{mM}$ monochloramine 605 or dichloramine to $100 \mathrm{nM}$ ranitidine buffered at $\mathrm{pH} 8$.

606

607

608

609

610

611

612 

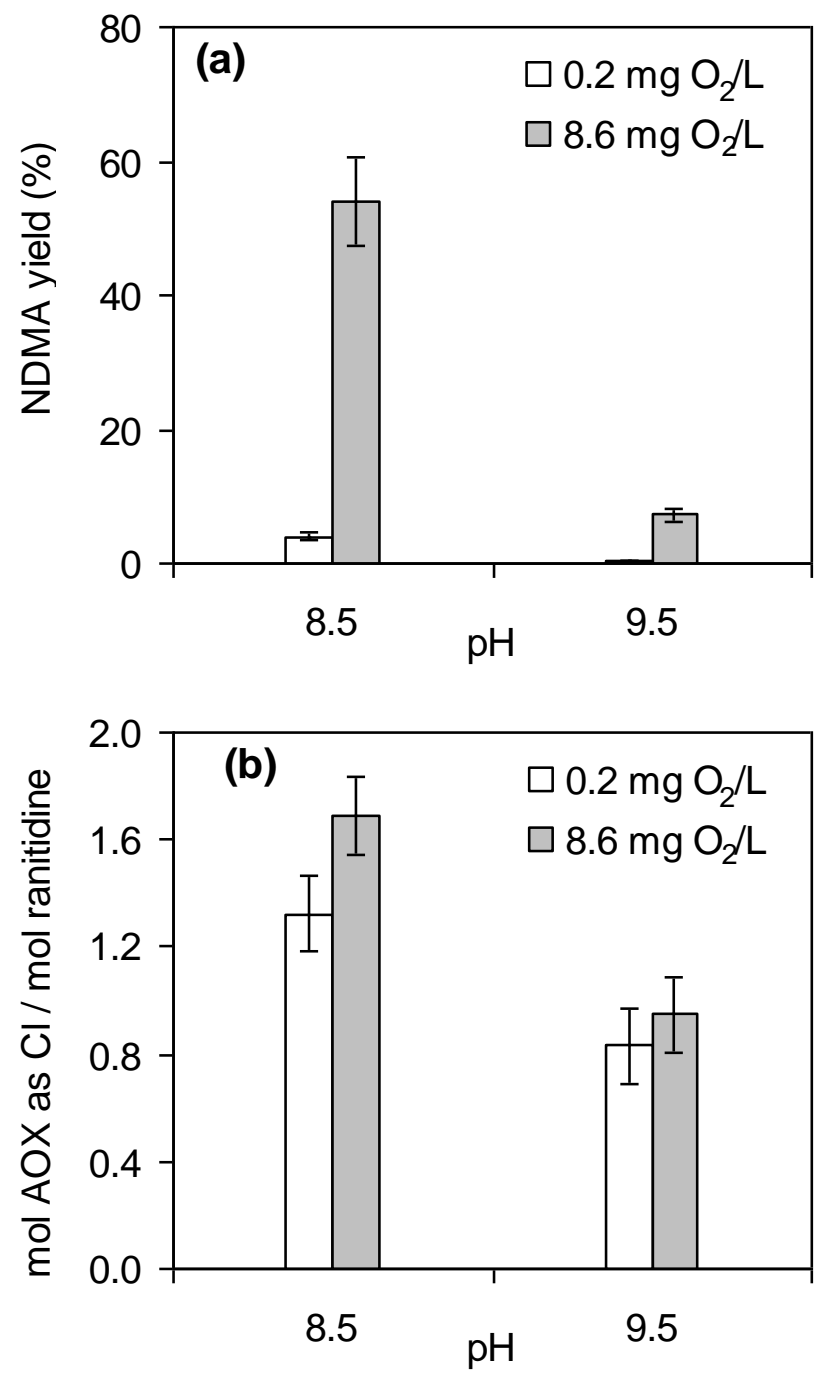

614

615 Figure 5. Effect of dissolved oxygen and $\mathrm{pH}$ on (a) NDMA and (b) AOX formation from $3 \mu \mathrm{M}$

616 ranitidine and $2.7 \mathrm{mM} \mathrm{NH}_{2} \mathrm{Cl}$, over $2 \mathrm{~h}$ with $10 \mathrm{mM}$ buffer. NDMA molar yields were calculated based 617 upon the initial ranitidine concentration. 


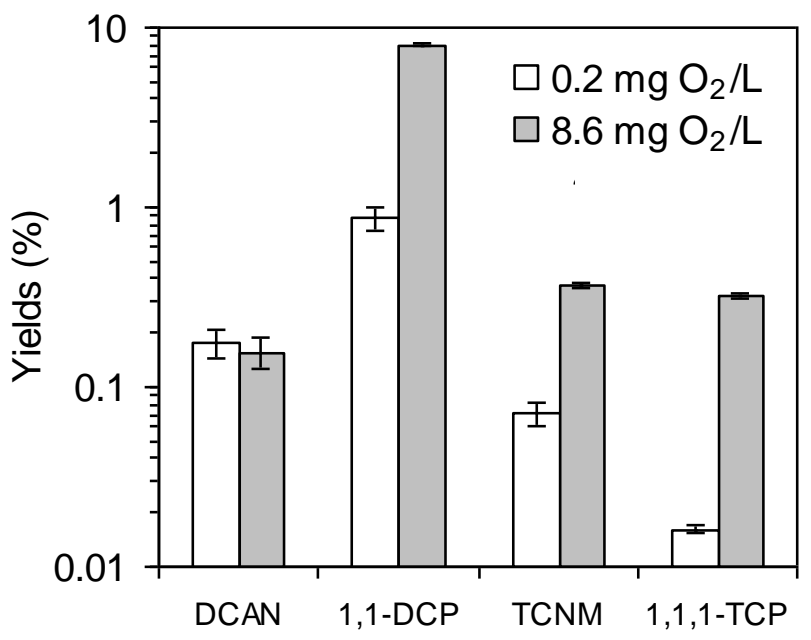

618

619 Figure 6. Effect of dissolved oxygen on DCAN, 1,1-DCP, TCNM and 1,1,1-TCP formation from $3 \mu \mathrm{M}$ 620 ranitidine and $2.7 \mathrm{mM} \mathrm{NH}_{2} \mathrm{Cl}$ over $2 \mathrm{~h}$ at $\mathrm{pH} 8.5$ with $10 \mathrm{mM}$ phosphate buffer. 